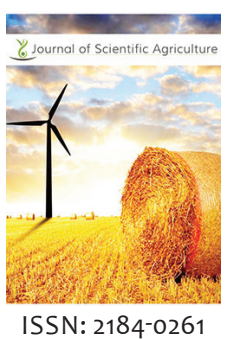

Received: May 12, 2020 Accepted: June 06,2020 Published: June 04,2020

*Corresponding Author: E. N. Mbah Email: evanmbah@gmail. com*

\section{Devastating impacts of flood disaster among rural households in Benue State, Nigeria}

\author{
R. K. Jiriko', E. N. Mbah*, N. E. Amah² \\ 'Department of Agricultural Extension and Communication, Federal University of Agriculture, Makurdi, Nigeria, \\ ${ }^{2}$ Federal College of Animal Heath and Production Technology, Vom, Plateau State, Nigeria
}

\begin{abstract}
The study was carried out to determine devastating impacts of flood disaster among rural households in Benue State, Nigeria. Questionnaire was used to collect data from a sample of 145 respondents used for the study. Data collected for the study were analyzed using mean score. Findings indicated that the major causes of flood disaster were poor level of public awareness campaign on flood hazard $(\bar{x}=2.00)$, increased impermeability due to urbanization $(\bar{x}=2.00)$, overflowing dams $(\bar{x}=2.00)$, building on water ways and drainage channels $(\bar{x}=2.00)$, flood plain being occupied by human settlement and economic activities $(\bar{x}=1.41)$, blockage of flood path with sediment deposit $(\bar{x}=1.31)$ and increase in rainfall $(\bar{x}=1.30)$. Rendering of rural dwellers homeless $(\bar{x}=2.47)$, fills homes with dirty water and refuse $(\bar{x}=2.43)$, blockage of road networks $(\bar{x}=2.42)$, disruption of economic activities $(\bar{x}=2.40)$, destruction of farmlands $(\bar{x}=2.40)$, increase in household food insecurity $(\bar{x}=2.35)$, destruction of crops and livestock $(\bar{x}=2.30)$, damages stored farm produce $(\bar{x}=2.24)$ and loss of lives and property $(\bar{x}=2.12)$ were effects of flood disaster on rural households. Based on the findings of the study, there arises the need for government at all levels and non-governmental organizations to intensify efforts in creation of awareness for people living in flood prone areas to relocate to a safer place in order to avoid loss of life and disruption of economic activities.
\end{abstract}

KEYWORDS: Flood disaster, effects, economic losses, rural households, environmental hazard,

\section{INTRODUCTION}

Floods are the most common and widespread of all natural disaster. Nigeria is one of the highly flood prone countries in the world. About 40 million hectares of land in Nigeria is prone to floods [1]. Flood as a natural event or occurrence where a piece of land (or area) that is usually dry, suddenly gets submerged under water. Parker [2] defined flood as an excess accumulation of water across a land surface. Floods cause damage to houses, industries, public utilities and property resulting in huge economic losses, apart from loss of lives. Though it is not possible to control the flood disaster totally, by adopting suitable structural and non-structural measures the flood damages can be minimized. In order to plan any flood management measure latest, reliable, accurate and timely information is required. In this context satellite remote sensing plays an important role.

However, flooding is also a natural hydrological process required by some plants and animals to thrive. Flooding may occur as an overflow of water from water bodies such as a river, lake or ocean in which the water overtops or breaks levees, resulting in some of that water escaping its usual boundaries [3]. Eychaner [4] opined that flood may occur due to an accumulation of rainwater on saturated ground in an aerial flood. While the size of a lake or other body of water will vary with seasonal changes in precipitation and snow melt, these changes in size are unlikely to be considered significant unless they flood property or drown domestic animals.

Floods often cause damage to homes and businesses if they are in the natural flood plains of rivers. Riverine flood damage can be eliminated by moving away from rivers and other bodies of water, people have traditionally lived and worked by river side because the land is usually flat and fertile. Also, provides easy travel and access to commerce and industry.

Floods are caused by many factors, namely; heavy rainfall, highly accelerated snowmelt, severe winds over water, unusual high tide, tsunamis or failure of dams, levees, retention ponds, or other structures that retained the water. Ojo and Adebayo [5] identified absence of drainage channels, blockage of flood path and absence of vegetative cover as the major causes of flooding. This finding conforms to that of Mudiaga [6] who made similar findings. Hassan [7] identified occupation of

Copyright: ๑) The authors. This article is open access and licensed under the terms of the Creative Commons Attribution License (http://creativecommons.org/licenses/by/4.0/) which permits unrestricted, use, distribution and reproduction in any medium, or format for any purpose, even commercially provided the work is properly cited. Attribution - You must give appropriate credit, provide a link to the license, and indicate if changes were made. 
flood plains with human settlement, increased impermeability due to urbanization and blockage of flood path with litter and sediment deposits as farmer's perception on the causes of flood disaster.

According to the Inter-governmental Panel on Climate Change (IPCC) [8], flood disaster has created immense challenges in poor and vulnerable communities. The effects of these changes on hunger and under-nutrition have been felt across the world, with a disproportionate impact on vulnerable communities in less developed countries especially Nigeria with Benue State because most rural communities do not have the resources and capacities to adapt and respond. It was against this backdrop that this study determined devastating impacts of flood disaster among rural households in Benue State, Nigeria. This raised the following research questions that are pertinent to the study. What are the causes of flood disaster? What are the effects of flood disaster on rural households?

Specifically, the study sought to:

i. identify the causes of flood disaster; and

ii. determine the effects of flood disaster on rural households.

\section{METHODOLOGY}

The study was conducted in Benue State, Nigeria. The State is one of the six states constituting the North Central region of Nigeria. The State is situated within the middle belt of Nigeria. It is located between longitudes $6^{0} 33 \mathrm{E}$ and $10^{\circ} \mathrm{E}$ and latitudes $6^{0} 30 \mathrm{~N}$ and $8^{0} 10 \mathrm{~N}$. The state has its capital in Makurdi. The state is administratively divided into three zones namely; Zone A (Eastern Zone), Zone B (Northern Zone) and Zone $\mathrm{C}$ (Central Zone) and has twenty three (23) local government areas.

The State has a population of 4,253,641 million people (National Population Commission (NPC), [9] and covers a total land area of about 33,955 square kilometers. The state is made up of 413,159 farm families Benue State Agricultural and Rural Development Authority (BNARDA), [10]. The state is bounded by Nasarawa State in the north, Taraba State in the east, Cross-River State in the south, Enugu State in the southwest, Ebonyi State in the south central, Kogi state in the west and in the south east by Cameroon Republic.

The predominant occupation of inhabitants of Benue State is farming with over $80 \%$ engaged in the occupation and highly noted for cultivation of arable crops like yam, cassava, rice, soybean, maize and other staples. Livestock especially small ruminants are reared extensively in this area. The main source of livelihood of the people is agriculture, hence the Food Basket of the Nation. The state has two distinct seasons, dry and rainy seasons. The wet season starts in April and ends in November while the dry season starts in December and ends in March. The wet or rainy season with the mean precipitation of $1500 \mathrm{~mm}$ has two peaks May/June and August/September. The dry season also called harmattan is characterized by north-eastern winds. Flood being the worst hit in 2012. This is obtainable in the country

has destroyed a lot of lives and properties in Nigeria, especially in Benue State where its occurrence is on annual basis.

The population of the study comprised head of households of farm families in Benue state, Nigeria. Zone B was purposively selected for this study out of the three zones because of persistent occurrence of flood in the area. Two local government areas were selected out of eight local government areas. The selected local government areas are Guma and Makurdi because these LGAs were the worst hit in the 2012 flood disaster. Four communities were selected from each of the local government areas using simple random sampling technique while heads of households were also selected from each of the communities, giving a sample size of 145 respondents used for the study. Interview schedule/ questionnaire was used for data collection while data were analyzed using frequency, percentage and mean score.

\section{RESULTS AND DISCUSSION}

\section{Causes of Flood Disaster}

Results in Table 1 presented causes of flood disaster which include poor level of public awareness campaign on flood hazard $(\bar{x}=2.00)$, increased impermeability due to urbanization $(\bar{x}=2.00)$, overflowing dams $(\bar{x}=2.00)$ and building on water ways and drainage channels

$(\bar{x}=2.00)$, flood plain being occupied by human settlement and economic activities $(\bar{x}=1.41)$, blockage of flood path with sediment deposit $(\bar{x}=1.31)$, increase in rainfall $(\bar{x}=1.30)$, high level of defective drainage on the streets $(\bar{x}=1.27)$, among others. However, and absence of vegetal cover in the e $\bar{x}$ nvironment $(\bar{x}=1.15)$ and absence of drainage channel $(\bar{x}=1.10)$ were not considered a perceived cause of flood disaster in the study area. This finding is in agreement with Hassan [7] who reported occupation of flood plain with human settlement and economic activities, increased impermeability due to urbanization and blockage of flood path with sediment deposits are the main causes of flood. The finding also agrees previous report that stated heavy rainfall and high level of streets with defective drainage as the major causes of flood disaster. Dappa [11] reiterated that overflowing of dams, building on water ways and drainage channels as well as poor level of public awareness campaign on flood hazards as the major cause of flood disaster.

Table 1: Mean score of perceived causes of flood disaster

\begin{tabular}{lc}
\hline Causes & Mean score \\
\hline Increase in rainfall & 1.30 \\
Absence of drainage channel & 1.15 \\
High level defective drainages on the streets & 1.27 \\
Blockage of flood path with sediment deposits & 1.31 \\
Flood plain being occupied by human settlement and & 1.41 \\
economic activities & \\
Poor level of public awareness campaign on flood hazards & 2.00 \\
Increased permeability due to urbanization & 2.00 \\
Absence of vegetative cover in the environment & 1.10 \\
Overflowing of dams & 2.00 \\
Building on water ways and drainage channels & 2.00 \\
\hline
\end{tabular}




\section{Effects of Flood Disaster on Rural Households}

Table 2: Mean score of effects of flood disaster on the respondents

\begin{tabular}{lc}
\hline Effects & Mean score \\
\hline Destruction of crops and livestock & 2.30 \\
Blockage of road networks & 2.42 \\
Loss of lives and properties & 2.12 \\
Increase in household food insecurity & 2.35 \\
Destruction of farmlands & 2.40 \\
Farmlands exposed to soil erosion & 1.84 \\
High rate of poverty & 2.03 \\
Pollution of drinking water sources & 1.66 \\
Damages stored farm produce & 2.24 \\
Renders rural dwellers homeless & 2.47 \\
Exposure to environmental health hazards & 1.50 \\
Loss of crop nutrients from the soil & 1.38 \\
Fills homes with dirty water and refuse & 2.43 \\
Disruption of economic activities & 2.40 \\
\hline
\end{tabular}

Table 2 showed the mean score of effects of flood disaster as indicated by the respondents which were renders rural dwellers homeless $\left(x^{-}=2.47\right)$, fills homes with dirty water and refuse $\left(x^{-}=2.43\right)$, blockage of road networks $\left(x^{-}=2.42\right)$, disruption of economic activities $\left(x^{-}=2.40\right)$, destruction of farmlands $\left(x^{-}=2.40\right)$, increase in household food insecurity $\left(x^{-}=2.35\right)$, destruction of crops and livestock $\left(x^{-}=2.30\right)$, damages stored farm produce $\left(x^{-}=2.24\right)$, loss of lives and property $\left(x^{-}=2.12\right)$ and high rate of poverty $\left(x^{-}=2.03\right)$. The finding is in agreement with Oyekale et al. [12] who noted that flooding is an environmental problem which results in death of people and livestock as well as loss of property, blockage of road networks and disruption of economic activities.

\section{CONCLUSION AND RECOMMENDATIONS}

The study concludes that major causes of flood disaster in the study area were inadequate provision of information on the dangers associated with living in flood prone areas, loss of arable crop lands resulting from expansion of cities due to urbanization, overflow of dams, erecting structures on drainage channels, inability of the inhabitants to clean up available gutters and drainage channels resulting from deposits of waste and refuse. Findings of the study revealed the devastating impact flood disaster had on the respondents in terms of displacement whereby most of the rural dwellers were rendered homeless because their houses were submerged in flood, filling their homes with dirty water and refuse, blockage of road networks, disruption of economic activities, destruction of farmlands, destruction of crops and livestock, damages stored farm produce, loss of lives and property. These factors impact negatively on the rural households which lead to increase in food insecurity. Based on the findings of the study, there arises the need for government at all levels and non-governmental organizations to intensify efforts in creation of awareness for people living in flood prone areas to relocate to a safer place in order to avoid loss of life and disruption of economic activities. It also highlights that rural households should ensure good sanitation of their environment in order to enhance free flow of water in the drainage channels thereby preventing flood disaster.

\section{REFERENCES}

1. National Metrological Agency (2014). Flood disasters in Nigeria https://nimet.gov.ng.

2. Parker, S.J. (2017). Surface water flood warnings requirements and potential in England and WalesAppl. Geogr., 31 (3) (2011), 891-900.

3. Myrtle, D. (2016). Cooperation between Local Authority and Communities: Reducing Flood Disaster Risk in Dagupan City, Philippines. Asian Disaster Preparedness Center. Available at URL: http://www.adpc.net.

4. Eychaner, J.H. (2015). Lessons from a 500-year record of flood elevations, Association of State Flood plain Managers, Technical Report, 7.

5. Ojo, E. and Adebayo, P (2017). Food Security in Nigeria: An Overview. European Journal of Sustainable Development, 1(2), 199-222.

6. Mudiaga, O. (2017). Analysis of soil and land cover parameters for flood hazard assessment: A case study of the lyara watershed. Unpublished project report, Delta State University Abraka, Nigeria

7. Hassan, A. (2013). Impact of flood disaster among farming communities in Kebbi State. Unpublished project report, Kebbi State University.

8. Intergovernmental Panel on Climate Change (IPCC). (2017). Climate Change 2017: Impacts, Adaptation Vulnerability. Contribution of Working Group II to the Third Assessment Report of the Intergovernmental Panel on Climate Change. Geneva: UNEPMMO.

9. National Population Commission (NPC) (2006). Nigerian Demographic and Health Survey (NDHS): Key findings. NPC, Analytical Report of National Level, 20-25.

10. Benue State Agricultural and Rural Development Authority (BNARDA) (2008). Benue State Agricultural Development Agency (BNARDA). Agricultural production recommendations for Benue State. Extension Bulletin, 3(1), 30-33.

11. Dappa, G. (2017). Effective Financial Mechanisms at the national and local level for Disaster Risk Reduction. United Nations Capital Development Fund.

12. Oyekale, A.S., Oladele, O.I. and Mukela, F. (2013). Impacts of flooding on coastal fishing folks and risk adaptation behaviours in Epe, Lagos State. Journal of Food Agriculture and Environment, 12 (1), 339-346. 